\title{
Self Monitoring of Increased Interdialytic Weight Gain Crisis on Hemodialisys Client with Health Control Card in Mardi Waluyo Hospital in Blitar Indonesia
}

\author{
Supono \\ Program Study Diploma IV of Nursing at Lawang, Malang State Health Polytechnics, Indonesia
}

\begin{abstract}
End of Stage renal failure is a chronic kidney disease that requires special treatment such as hemodialysis. It is often occurs an increase in weight which comes from fluid overload due to the inability of kidney to perform the glomerular filtration functions by the nephron. This research was conducted on July $25^{\text {th }} 2015$ until August $25^{\text {th }} 2015$. Total samples of this research were 23 respondents. Purposive sampling technique was used to obtain the samples. Statistical test which used was paired samples t test with the result as follow: there was no significant difference between weight before and after self monitoring ( $p=0.470)$. There was significant difference in systolic blood pressure between before and after self monitoring $(p=0.000)$. This research suggest that using the technique of Self Monitoring Health Control Card can be useful for client who undergo hemodialysis.
\end{abstract}

Keywords: hemodialysis; self-monitoring; blood-pressure; renal-failure

\section{Introduction}

When a patient is on End Stage of Renal Disease (ESRD), the only choice to maintain body function is kidney replacement, i.e., either dialysis or kidney transplantation. At the moment, hemodialysis is the most frequent kidney replacement therapy conducted and the number is increasing from time to time. The main objective of hemodialysis is to control uremia, excess of fluid and electrolytes imbalances. A patient with dialysis treatment needs health education, lifestyle modification, diet knowledge and monitoring of fluid balance to avoid worse condition due to toxin and fluid storage. The main issue for patient with ESRD is inability to manage fluid intake that results in overweight whenever proceeds the next hemodialysis i.e., Interdialytic Weight Gain IDWG).

Nowadays, Mardi Waluyo Hospital in Blitar City serve more or less 10 patients each day. There are 124 patients who need hemodialysis continuously and most of them have increasing IDWG. The increased IDWG in hemodialysis patients is also influenced by a bad monitoring to control body weight gain due to the absence of patient record. This condition needs attention so that a record model to control IDWG is useful by using Health Control Card. The objective of the research is to investigate whether there is a difference of IDWG between before and after self monitoring using Health Control Card at Mardi Waluyo Hospital in Blitar City.

\section{Methods}

This research conducted by analytical observation. The Study Population was 124 patients who needs proceeds hemodialysis in Mardi Waluyo Hospital in Blitar City. A number of 23 patients were chosen as the sample of the study using purposive sampling method. This research was conducted in renal unit at Mardi Waluyo Hospital during the period of $25^{\text {th }}$ Juli until $25^{\text {th }}$ August 2015. The collection of data covered nursing documentation for 3 periods of previous hemodialysis on the Health Control Card and 3 episodes that has been recorded by the patients during the hemodialysis session. Statistical analysis was done using paired samples t-test.

\section{Results}

Observation of samples body weight showed as can be seen the below table

Table 1: Body Weight Measurements

\begin{tabular}{|l|l|l|l|l|c|}
\hline \multicolumn{1}{|c|}{ Samples } & N & Mean & Min & Max & CI 95\% \\
\hline Pre Self Monitoring & 23 & 63.3 & 38 & 84 & $58.3817-68.227$ \\
\hline Post Self Monitoring & 23 & 62.3 & 38 & 84 & $56.1490-68.4510$ \\
\hline
\end{tabular}

The record of blood pressure records of 23 patients can be seen in the table below

Table 2: Measurements of Blood Pressure

\begin{tabular}{|c|c|c|c|c|c|}
\hline Blood Pressure & N & Mean & Min & Max & CI 95\% \\
\hline Systolic Pre Self Monitoring & 23 & 149 & 117 & 191 & $140.34-157.82$ \\
\hline Diastolic Pre Self Monitoring & 23 & 85.3 & 73.7 & 100 & $82.11-88.62$ \\
\hline Systolic Post Self Monitoring & 23 & 142 & 115 & 185 & $133.79-150.37$ \\
\hline Diastolic Post Self Monitoring & 23 & 81.7 & 69 & 99 & $81.74-88.62$ \\
\hline
\end{tabular}

The t-test analysis can be seen in the table below

Table 3: t-test analysis results

\begin{tabular}{|l|c|c|c|}
\hline & $\mathrm{t}$ & $\mathrm{df}$ & $\begin{array}{c}\text { Sig } \\
\text { (2-tailed) }\end{array}$ \\
\hline Bodyweight (pre-test) - Bodyweight (post test) & .736 & 22 & .470 \\
\hline Systolic (pre-test) - Systolic (post test) & 6.176 & 22 & .000 \\
\hline Diastolic (pre-test) - Diastolic (post test) & 9.039 & 22 & .000 \\
\hline
\end{tabular}




\section{Discussion}

Table 1 shows that there is a decrease in patients body weight after the use of Health Control Card. This may be explained that the patient has implemented fluid restriction management because the main source of increasing body weight is due to fluid retention in the body. By using Health Control Card, the patients applied self limitation of fluid intake. Although the difference between pre self monitoring and post monitoring is not statistically significant, the is an observed body weight reduction. This could be explained by the fact that the patient were taught the use of the Health Control Card in very recent period so that they may not apply all of the instruction of the use of the Card.

The decrease of blood pressure occurred as the result of the decrease of fluid volume in the body. Fluid retention in the body influence vascular pressure since vascular pressure elevated when there is a space pressure due to fluid overload. The lowered blood pressure either systolic of diastolic provided evidence that fluid restriction is very important in managing blood pressure among patient with hemodialysis. It can be predicted that if all of the patient conducted self monitoring using the Health Control Card strictly as they were instructed, it can be expected that the patient body weight and blood pressure would lower simultaneously

\section{Conclusion}

Patient blood pressure either systolic or diastolic showed a decrease after the patient use Health Control Card when it was compared to the condition before the use of Health Control Card. The patients body weight was not statistically different between before and after the use of the Card. However, there was no body weight gain after the patient implement self monitoring.

\section{References}

[1] Ignatavicius, D.D., \& Workman, M.L. (2006). MedicalSurgical Nursing: Critical Thingking for Collaborative Care. $5^{\text {th }}$ edition. St Louis: Elsevier Sounders.

[2] Kallenbach, J.Z ; Gutch, C.F ; Martha, S.H \& Corca, A.L. (2005). Review of Hemodialysis for Nurses and Dialysis Personnel. $7^{\text {th }}$ edition. St Louis: Elsevier Mosby.

[3] Le Mode, P.; Burke, K.M. (2008). Medical Surgical Nursing: Critical Thinking in Client Care. $6^{\text {th }}$ edition. New Jersey: Prentice Hall.

[4] Smeltzer, S.C. et al. (2008). Brunner \& Suddarth's: Textbook of Medical Surgical Nursing. $11^{\text {th }}$ Edition. Philadelphia: Lippincott.

[5] Sudoyo, A.W. ; Setiyohadi, B ; Alwi, I ; Simadibrata, M \& Setiati, S. (2007). Buku Ajar Ilmu Penyakit Dalam. Edisi ke 4 jilid 1. Jakarta: Fakultas Kedokteran Universitas Indonesia. 